\title{
PALYGORSKITE FROM PADASJOKI, SOUTHERN FINLAND
}

\author{
KRISTIAN LINDQVIST and ILKKA LAITAKARI
}

\begin{abstract}
LINDQVIST, K. and LAITAKARI, I. (1981) Palygorskite from Padasjoki, southern Finland, Bull. Geol. Soc. Finland 53-2, 91-95.

Monoclinic palygorskite with the unit cell $\mathrm{a}_{0}=12.689 \AA, \mathrm{b}_{0}=$ 17.845 $\AA, c_{0}=5.119 \AA$ and $\beta=91.22^{\circ}$ has been found at Padasjoki, southern Finland. The mineral is thought to be of hydrothermal origin. Monoclinic symmetry is connected with an ordered Mg-Al substitution, although owing to the low $\Delta \mathrm{d}_{12 \overline{1}}-121$ value observed a low degree of ordering is suggested.
\end{abstract}

Kristian Lindqvist and Ilkka Laitakari: Geological Survey of Finland, SF-02150 Espoo 15, Finland.

\section{Introduction}

The first reliable find of palygorskite, ( $\mathrm{Mg}, \mathrm{Al})_{2} \mathrm{Si}_{4} \mathrm{O}_{10}(\mathrm{OH}) \cdot 4 \mathrm{H}_{2} \mathrm{O}$, in Finland has been made at Padasjoki, southern Finland. Although Kazakov (1911) reported that palygorskite had been found in a museum sample from Stansvik, Finland, later investigations of the Stansvik quarry (Aurola 1956) indicated the existence of only sepiolite. Within the scope of the present study the Stansvik mountain leather and asbestos minerals were re-investigated, but no palygorskite could be found.

Uusinoka (1975, p. 82) reported that no sepiolite-palygorskite was encountered in his study of rock-gouge in fractures of Finnish bedrock.

White mountain leather occurs as thin (about $1 \mathrm{~mm}$ ) sheets (Fig. 1) in opened fissures in a road cut north of the lake Mäkientaustanjärvi at Padasjoki (map sheet 214307; coordinates $\mathrm{x}=6801.62, \mathrm{y}=561.08)$. $\mathrm{X}$-ray diffraction studies proved the mountain leather to be palygorskite. The granitic host rock is partly altered and yellowish green due to epidotization.

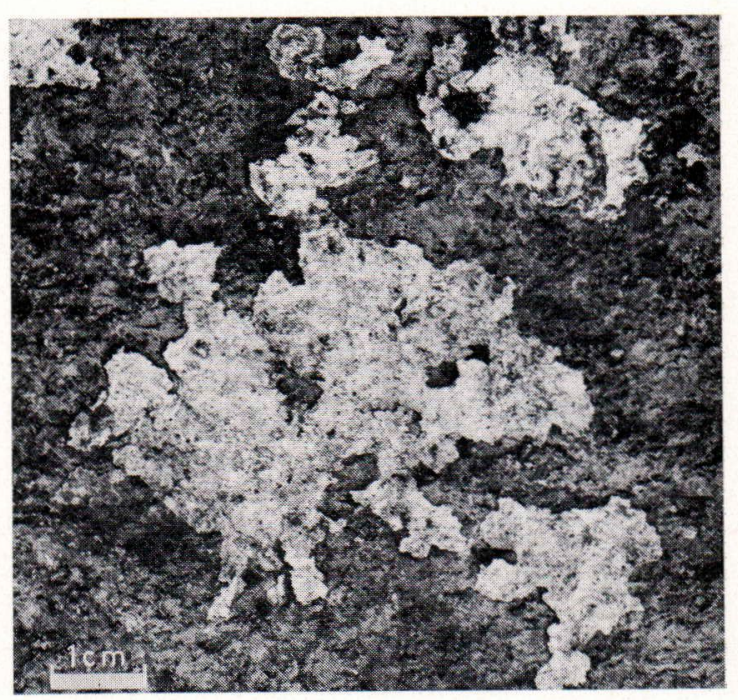

Fig. 1. Palygorskite as thin sheets on granitic host in an opened fissure. 


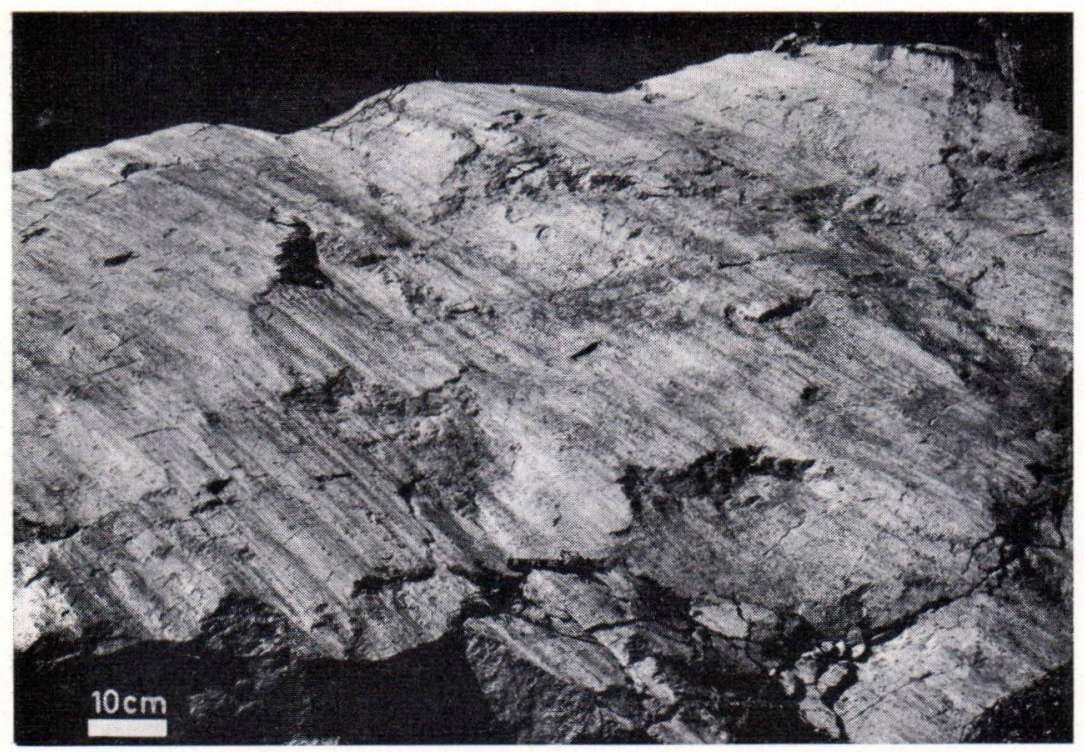

Fig. 2. Slickensides in the fault zone at Padasjoki.

\section{Geological setting}

The bedrock of the area is part of the deeperoded base of the Svecokarelides. WSW from Padasjoki there is a fault zone striking $\mathrm{N} 65^{\circ}$ E. Several outcrops show mylonitization, quartz-epidote dykes and slickensides (Fig. 2). According to Laitakari (1971), the zone can be traced for 'several kilometres along the contact between porphyritic granodiorite and biotite gneiss. Some small granite areas have also been met with in the region. Morphologically the fault zone manifests itself as the straight valley- and watercourse nearby (Rautajärvi-Pintalammi-Särsjärvi). In a road cut close to the lake Pintalammi a diabase dyke was found that is thought to belong to the roughly 1600 -Ma-old olivine diabase dyke swarm of Häme (cf. Laitakari 1969). Small quantities of palygorskite were also identified in fissures of this dyke. Quartz-epidote dykes in the diabase indicate that movements took place in the fault zone after the emplacement of the diabase. Lau- montite-leonhardite-, calcite- and montmorillonite-bearing veins are met with in the fault zone.

\section{Texture and chemical composition}

Scanning electron microscopy showed that the palygorskite occurs as interwoven fibres (Fig. 3), the same texture as is exhibited by the mineral in other parts of the world, for example in the Puente Hills in U.S.A. (Henderson et al. 1973), at Stjernøy in Norway (Salter and Appleyard 1974) and at Fergana in U.S.S.R. (Mironenko 1970). This texture is responsible for the leathery character of the sample. The observed indices of refraction are $\alpha^{\prime}=1.520 \pm 0.005$ and $\gamma^{\prime}=1.545 \pm$ 0.005 .

Table 1 gives the chemical composition determined by XRF methods (water by the Penfield method). The low total is believed to be due to a deficiency of water, because rechecking of the composition by OES methods did not show any further elements. 
There are eight tetrahedral and five octahedral sites in the palygorskite structure. Of the octahedral sites $4-4.25$ are filled. Aluminium occupies 28-59 \% and magnesium $29-76 \%$ of the occupied sites (Zelazny and Calhoun 1977). The structural formula for the palygorskite from Padasjoki, calculated in accordance with Tien (1973) on the basis of 21 oxygens of dehydrated material is

$\mathrm{Si}_{7.47} \mathrm{Al}_{0.53}\left(\mathrm{Al}_{2.03} \mathrm{Fe}^{3+}{ }_{0.18} \mathrm{Mg}_{1.36} \mathrm{Ti}_{0.04} \mathrm{Mn}_{0.01}\right) \mathrm{O}_{21}{ }^{-}$ $\mathrm{Ca}_{0.15} \mathrm{Na}_{0.16} \mathrm{~K}_{0.30} \mathrm{P}_{0.05}$.

According to Church and Velde (1979), some of the zeolitic $\mathrm{Ca}$, and possibly $\mathrm{Na}$ and $\mathrm{K}$,

Table 1. Chemical composition of palygorskite from Padasjoki (analyst V. Hoffrén).

\begin{tabular}{|c|c|c|c|}
\hline & $\mathrm{SiO}_{2}$ & $52.95 \%$ & \\
\hline & $\mathrm{TiO}_{2}$ & 0.33 & \\
\hline & $\mathrm{Al}_{2} \mathrm{O}_{3}$ & 15.38 & \\
\hline & $\mathrm{Fe}_{2} \mathrm{O}_{3} *$ & $1.72 》$ & \\
\hline & $\mathrm{MnO}$ & $0.08 \gg$ & \\
\hline & MgO & $6.46 \gg$ & \\
\hline & $\mathrm{CaO}$ & $1.00 \gg$ & \\
\hline & $\mathrm{Na}_{2} \mathrm{O}$ & $0.59 \gg$ & \\
\hline & $\mathrm{K}_{2} \mathrm{O}$ & $1.66 \gg$ & \\
\hline & $\mathrm{P}_{2} \mathrm{O}_{5}$ & $0.44 \gg$ & \\
\hline & $\mathrm{H}_{2} \mathrm{O}$ tot. & $15.80 》$ & \\
\hline & $\mathrm{CO}_{2}$ & $0.33 »$ & \\
\hline & $\mathrm{Ga}_{2} \mathrm{O}_{3}$ & $0.004 »$ & \\
\hline & $\mathrm{Sc}_{2} \mathrm{O}_{3}$ & $0.008 »$ & \\
\hline & $\mathrm{CeO}_{2}$ & $0.25 \gg$ & \\
\hline & $\mathrm{La}_{2} \mathrm{O}_{3}$ & $0.12 》$ & \\
\hline & $\mathrm{Nb}_{2} \mathrm{O}_{5}$ & $0.007 »$ & \\
\hline & & $97.129 \%$ & \\
\hline \multicolumn{4}{|c|}{$\begin{array}{l}\text { Number of main ions calculated on the basis of } 21 \\
\text { oxygens of dehydrated material }\end{array}$} \\
\hline & $\mathrm{Si}$ & 7.47 & \\
\hline & $\mathrm{Ti}$ & 0.04 & \\
\hline & $\mathrm{Al}$ & 2.56 & \\
\hline & $\mathrm{Fe}^{3+}$ & 0.18 & \\
\hline & $\mathrm{Mn}$ & 0.01 & \\
\hline & $\mathrm{Mg}$ & 1.36 & \\
\hline & $\mathrm{Ca}$ & 0.15 & \\
\hline & $\mathrm{Na}$ & 0.16 & \\
\hline & $\mathrm{K}$ & 0.30 & \\
\hline & $\mathrm{P}$ & 0.05 & \\
\hline
\end{tabular}

* Total $\mathrm{Fe}$ as $\mathrm{Fe}_{2} \mathrm{O}_{3}$

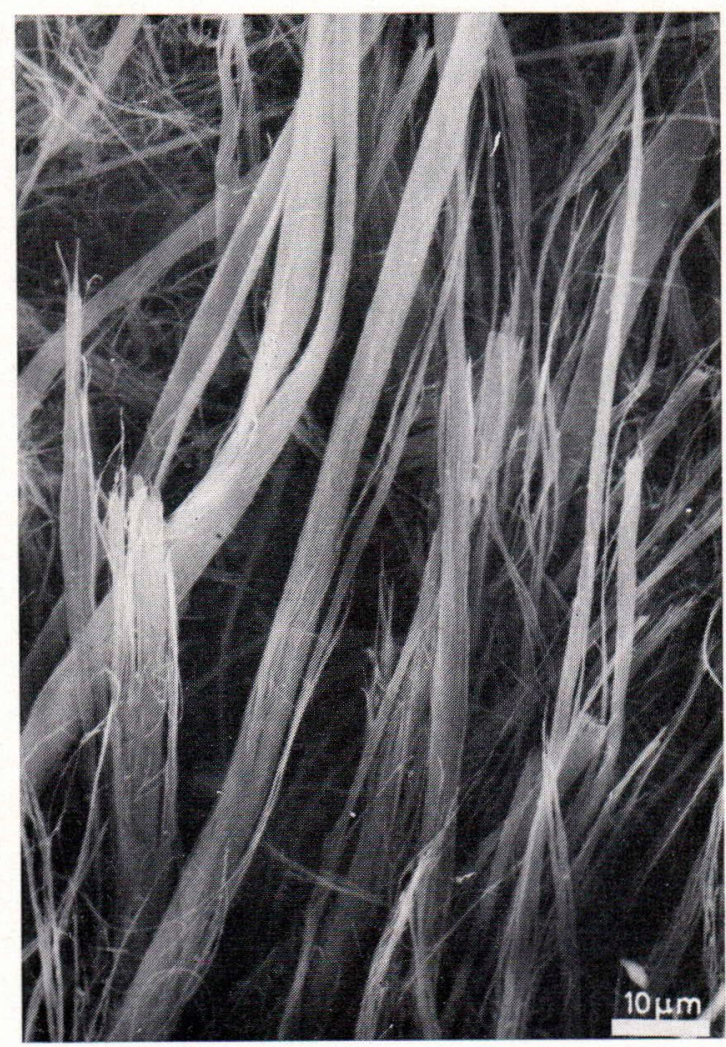

Fig. 3. Interwoven fibres of palygorskite. Scanning electron micrograph by R. Törnroos.

substitute for $\mathrm{Mg}$ in the octahedral position. This very likely applies to the palygorskite from Padasjoki, because octahedral Al seems high (about $56 \%$ of the occupied sites) without these elements substituting for $\mathrm{Mg}$.

\section{X-ray diffraction studies}

The studies were conducted with a Philips wide-angle goniometer and Ni-filtered $\mathrm{Cu}$ radiation. Several sample preparation techniques, including a Lakeside resin preparation used by Salter and Appleyard (1974), were tested, but the best results were obtained by backloading pure mineral powder in an aluminium specimen holder. For cor- 
Table 2. X-ray data on palygonskite from Padasjoki.

\begin{tabular}{rrrr}
\hline hkl & d (obs.) & d (calc.) & I/I ${ }_{0}$ \\
\hline & & & \\
110 & 10.365 & 10.340 & 100 \\
200 & 6.336 & 6.343 & 10 \\
130 & 5.391 & 5.386 & 8 \\
040 & 4.465 & 4.461 & 17 \\
300 & 4.244 & 4.229 & 7 \\
$12 \overline{1}$ & 4.210 & 4.215 & 6 \\
$12 \overline{1}$ & 4.158 & 4.166 & 5 \\
201 & 4.033 & 4.025 & 2 \\
$21 \overline{1}$ & 3.929 & 3.927 & 2 \\
$24 \overline{0}$ & 3.646 & 3.649 & 6 \\
231 & 3.341 & 3.334 & 10 \\
311 & 3.175 & 3.175 & 15 \\
440 & 2.583 & 2.585 & 10 \\
002 & 2.559 & 2.559 & 7 \\
& 2.542 & & 9 \\
$16 \overline{1}$ & 2.527 & 2.526 & 9 \\
302 & 2.168 & 2.169 & 2 \\
& 2.128 & & 3 \\
600 & 2.113 & 2.114 & 3 \\
480 & 1.821 & 1.825 & 2 \\
570 & 1.798 & 1.798 & 3 \\
$1,10,1$ & 1.670 & 1.669 & 3 \\
801 & 1.506 & 1.506 & 2 \\
253 & 1.489 & 1.489 & 2 \\
403 & 1.344 & 1.343 & 3 \\
861 & & & \\
\hline
\end{tabular}

Lattice constants:

$$
\begin{aligned}
& \mathrm{a}_{0}=12.689 \AA \\
& \mathrm{b}_{0}=17.845 \AA \\
& \mathrm{c}_{0}=5.119 \AA \\
& \beta=91.22^{\circ}
\end{aligned}
$$

rect peak positions, $\mathrm{NaCl}$ was used as internal standard. X-ray data on the mineral studied are presented in Table 2 .

Splitting of the 121 peak indicates a monoclinic unit cell (Christ et al. 1969). The extinction for $\mathrm{hkO}$ reflections $(\mathrm{h}+\mathrm{k}=$ $2 \mathrm{n}+1$ ) observed by Christ et al. (op.cit.) was considered in indexing the pattern. Two of the peaks $(\mathrm{d}=2.542 \AA$ and $\mathrm{d}=2.128 \AA$ ) are possibly caused by illite impurities. Glycolation of the sample did not reveal an expanding component.

When the sample had been heated at $200^{\circ} \mathrm{C}$, $300^{\circ} \mathrm{C}$ and $400^{\circ} \mathrm{C}$ for one hour the $10.365 \AA$ peak became more and more faint and diffuse. At the same time a new peak appeared at about $9 \AA$. Van der Wel (1972) has reported disappearance of the $10.365 \AA$ peak on heating at $400^{\circ} \mathrm{C}$ but no new peak at $9 \AA$. According to VanScoyoc et al. (1979), the occurrence of the new $9 \AA$ peak is due to folding of the palygorskite structure on dehydration. Thus the folded structure represents the "anhydride» form (VanScoyoc et al., op.cit.). On heating palygorskite at $550^{\circ} \mathrm{C}$, Molloy and Kerr (1961) established almost total collapse of the structure.

\section{Discussion and conclusions}

The palygorskite from Padasjoki is thought to be of hydrothermal origin as a result of direct precipitation from a hydrothermal solution like the palygorskite from the Day Book dunite (Furbish and Sando 1976). The geology of the area shows several signs of hydrothermal activity, one of the more notable being the epidotization of the granitic rock on which the palygorskite is found. Alteration and epidotization of palygorskitebearing syenite on the Shetland Isles is regarded to be due to hydrothermal activity (Stephen 1954). At Stjernøy magnesium was leached from basaltic dykes during hydrothermal alteration (Salter and Appleyard 1974). A similar mode of formation is suggested for Padasjoki. Thus the magnesium needed for the formation of palygorskite originates from hydrothermal reactions in the diabase.

According to Nathan et al. (1970), the hydrothermal palygorskites seem to be monoclinic, but the sedimentary ones orthorhombic. The present study is consistent with this theory. The cooling rate seems to be much more critical for the symmetry than the temperature of formation. Furthermore, Nathan et al. (op.cit.) suggest that palygorskites with an ordered $\mathrm{Mg}-\mathrm{Al}$ octahedral substitution 
have monoclinic symmetry whereas disordered palygorskites have orthorhombic symmetry. Although Christ et al. (1969) proposed that the structure reflects the chemical composition, the present authors have not found any general correlation between symmetry and composition. We believe that there is a continuous series from the orthorhombic state with $\beta=90^{\circ}$ to the monoclinic state with a variable $\beta$-angle. As proposed by Nathan et al. (1970), this is probably due to the $\mathrm{Mg}-\mathrm{Al}$ order-disorder structure. Finally, we suggest that the degree of

\section{References}

Aurola, E. (1956) The fibrous sepiolite deposit of Stansvik. Bull. Comm. Géol. Finlande 172, 1338 .

Christ, C. L., Hathaway, J. C., Hostetler, P. B. and Shephard, A. O. (1969) Palygorskite: New X-ray data. Amer. Mineral. 54, 198-205.

Church, T. M. and Velde, B. (1979) Geochemistry and origin of a deep-sea pacific palygorskite deposit. Chem. Geol. 25, 31-39.

Furbish, W. J. and Sando, T. W. (1976) Palygorskite -by direct precipitation from a hydrothermal solution. Clay Minerals 11, 147-152.

Henderson, G., Stankov, O. and Fife, D. (1973) Palygorskite found in the northern Puente Hills near Pomona. California Geol. 26, 280-281.

Kazakov, A. V. (1911)

Казаков, А. В. (1911) Матеріалы къ изученію группы палыгорскита. Bull. Acad. Impér. Sci. St. Pétersbourg, VI Sér., V, 679-684.

Laitakari, I. (1969) On the set of olivine diabase dikes in Häme, Finland. Bull. Comm. Géol. Finlande 241, 65 pp.

- (1971) Kallioperäkartta, Pre-Quaternary rocks, sheet 2143, Padasjoki. Geological map of Finland $1: 100000$.

Mironenko, O. A. (1970) Authigenic palygorskite from Jurassic sediments of southern Fergana. Dokl. Akad. Sci., U.S.S.R. 195, 177-179.

Molloy, M. W. and Kerr, P. F. (1961) Diffractometer patterns of A.P.I. reference clay minerals. Amer. Mineral. 46, 583-605. ordering can be estimated from the splitting of the 121 peak. A high $\Delta \mathrm{d}_{12 \overline{1}-121}$ value, for example 0.232 (cf. Christ et al. 1969), would reflect a high degree of ordering, whereas a value of, say, 0.156 (cf. Tien 1973) reflects a medium degree of ordering. The value of 0.052 shown by the palygorskite from Padasjoki reflects a low degree of ordering.

Acknowledgements - Dr. Kai Hytönen kindly read the manuscript and Dr. Seppo Lahti gave helpful advice during the work. Mrs. Gillian Häkli corrected the English text.

Nathan, Y., Bentor, Y. K. and Wurtzburger, U. (1970) Vein palygorskites in Israel and Sinai; their origin and symmetry. Israel J. Chem. 8, $469-476$.

Salter, D. L. and Appleyard, E. C. (1974) An occurrence of vein palygorskite from the nepheline syenite at Lillebugt, Stjernøy, northern Norway. Norsk Geol. Tidsskr. 54, 329-336.

Stephen, I. (1954) An occurrence of palygorskite in the Shetland Isles. Mineral. Mag. XXX, 471480.

Tien, P. L. (1973) Palygorskite from Warren quarry, Enderby, Leicestershire, England. Clay Minerals 10, 27-34.

Uusinoka, R. (1975) A study of the composition of rock-gouge in fractures of Finnish Precambrian bedrock. Comment. Phys.-Math. 45, 101 pp.

VanScoyoc, G. E., Serna, C. J. and Ahlrichs, J. L. (1979) Structural changes in palygorskite during dehydration and dehydroxylation. Amer. Mineral. 64, 215-223.

Wel, D. van der (1972) Asbestos minerals from Kongsberg silver deposit. Norsk Geol. Tidsskr. $52,287-294$.

Zelazny, L. W. and Calhoun, F. G. (1977) Palygorskite, (attapulgite), sepiolite, talc, pyrophyllite, and zeolites. In: Minerals in soil environments. Co-eds Dixon, J.B. and Weed, S.B., Soil Sci. Soc. of America Inc., Madison, Wisconsin U.S.A., 948 pp.

Manuscript received, June 3, 1981. 